A $\mathrm{Cublications}$ Rec. Nat. Prod. 11:6 (2017) 547-551

records of natural

products

\title{
Pigment pattern of the Chilean mushroom Dermocybe nahuelbutensis Garrido \& E. Horak
}

\author{
Anne Greff ${ }^{1}$, Andrea Porzel ${ }^{1}$, Jürgen Schmidt ${ }^{1}$, Götz Palfner ${ }^{2}$ \\ and Norbert Arnold ${ }^{* 1}$ \\ ${ }^{1}$ Department of Bioorganic Chemistry, Leibniz Institute of Plant Biochemistry, Weinberg 3, D-06120 Halle \\ (Saale), Germany \\ ${ }^{2}$ Departamento de Botanica, Facultad de Ciencias Naturales y Oceanograficas, Universidad de \\ Concepcion, Casilla 160-C, Concepcion, Chile
}

(Received January 27, 2017; Revised May 29, 2017; Accepted June 8, 2017)

\begin{abstract}
Fruiting bodies of the Chilean mushroom Dermocybe nahuelbutenis Garrido \& E. Horak (syn.: Cortinarius nahuelbutensis (Garrido \& E. Horak) E. Valenz. \& G. Moreno) were chemically investigated for the first time and afforded the new dimeric anthraqinone 7,7'-emodinphyscion (1) beside the know anthraquinones dermolutein (2), endocrocin (3), skyrin (4) and the dimeric pre-anthraquinone derivative flavomannin C (5). The chemotaxonomic significance of the pigments is discussed.
\end{abstract}

Keywords: Dermocybe nahuelbutensis; fungal fruiting bodies; pigments; chemotaxonomic significance. (C) 2017 ACG Publications. All rights reserved.

\section{Fungal Source}

Fruiting bodies of the mushroom Dermocybe nahuelbutenis Garrido \& E. Horak (syn.: Cortinarius nahuelbutensis (Garrido \& E. Horak) E. Valenz. \& G. Moreno) were chemically investigated for the first time. The herein investigated specimens were collected in Chile, Región del Bio Bío, Concepción, $36^{\circ} 50^{\prime}$ $13^{\prime \prime} / 73^{\circ} 01^{\prime} 28^{\prime \prime}$ s. 1., 160 m.a.s.l., on soil beneath Nothofagus obliqua (Mirb.) Oerst. in a remnant of mixed native forest dominated by N. obliqua and Aextoxicon punctatum Ruiz \& Pav., in May 2012 (collection CONC-F0874, leg. et det. G. Palfner \& N. Arnold). Voucher specimens are deposited in the Fungarium of Concepción University (CONC-F). A duplicate is deposited at Leibniz Institute of Plant Biochemistry.

\section{Previous Studies}

The occurrence of neutral anthraquinones, anthraquinone carboxylic acids as well as mono- and dimeric pre-anthraquinones has proved as a valuable aid in the taxonomy of the genus Dermocybe $e^{1}$. The

"Corresponding author: E- Mail: narnold @ipb-halle.de (N. Arnold), Phone +49-345-55821310. 
Pigment pattern of the Dermocybe nahuelbutensis

isolation and structure elucidation on the pigments of European Dermocybe was mainly carried out in the past by the group of Steglich and for some Australasian species by the group of Gill [5-7]. Comparative paper- and thin layer chromatographic studies were so far performed on European Dermocybe species [816] as well as on taxa from North America [17], Australia [18] and New Zealand [19]. Only two South American species (D. amoena, D. icterina) occurring in Argentinia [19,20] and Chile [21] has been investigated to date.

\section{Present Study}

Air-dried and powdered fruiting bodies $(20 \mathrm{~g})$ were extracted exhaustively with acidified acetone. After evaporation of the solvent, the resulting crude extract ( $2.9 \mathrm{gr})$ was dissolved in water, partitioned with ethyl acetate and evaporated to dryness. Separation of the ethyl acetate extract by column chromatography on acetylated polyamide (Polyamid MN SC 6-AC, Macherey, Nagel \& Co., Düren) using a series of solvents with increasing polarity (benzene, ethyl acetate, acetone, methanol) yielded 11 fractions. Fraction 2 was chromatographed over silicagel 60 (70-230 mesh, Merck) using the isocratic solvent system toluene : ethyl acetate : chloroform 2:1:2 and yielded compound $\mathbf{1}(10 \mathrm{mg})$.

7,7'-Emodinphyscion (1): Yellow amorphous powder; $\mathrm{R}_{\mathrm{f}}=0.64$ (solvent toluene : ethylformiate : formic acid 10/5/3 v/v); UV (MeOH): $\lambda_{\max } 200,285,440,461 .{ }^{1} \mathrm{H}$ NMR $(600 \mathrm{MHz}, \mathrm{DMSO}-d 6): \delta(\mathrm{ppm})=2.49$ $\left(3 \mathrm{H}, \mathrm{s}, 3\right.$ ' $\left.-\mathrm{CH}_{3}\right), 2.51\left(3 \mathrm{H}, \mathrm{s}, 3-\mathrm{CH}_{3}\right), 4.00(3 \mathrm{H}, \mathrm{s}, 6-\mathrm{OMe}), 7.24$ (1H, br s-like, H-2'), 7.28 (1H, br s-like, H-2), $7.34(1 \mathrm{H}$, very br s, H-5'), $7.53(1 \mathrm{H}$, br s, H-5), 7.58 (1H, br s-like, H-4'), 7.64 (1H, br s-like, H-4), $11.99(1 \mathrm{H}, \mathrm{br} \mathrm{s}, \mathrm{OH}), 12.18(1 \mathrm{H}, \mathrm{br} \mathrm{s}, \mathrm{OH}), 12.5(1 \mathrm{H}, \mathrm{br} \mathrm{s}, \mathrm{OH}) .{ }^{13} \mathrm{C}$ NMR $(125 \mathrm{MHz}, \mathrm{DMSO}-d 6): \delta(\mathrm{ppm})$ $=21.5\left(2 \mathrm{x} \mathrm{CH}_{3}\right), 56.5\left(\mathrm{CH}_{3}, 6-\mathrm{OMe}\right), 103.0(\mathrm{CH}, \mathrm{C}-5), 107,8\left(\mathrm{C}, \mathrm{C}-8 \mathrm{a}^{\prime}\right), 110.4(\mathrm{C}, \mathrm{C}-8 \mathrm{a}), 112.6\left(\mathrm{C}, \mathrm{C}-7^{\prime}\right)$, 113.5 (C, C-9a'), 113.7 (C, C-9a), 115.5 (C, C-7), 120.3 (CH, C-4'), 120.6 (CH, C-4), 124.0 (CH, C-2'), 124.2 (CH, C-2), 132.8 (C, C-4a'), 132.9 (C, C-4a), 134.1 (C, C-10a'), 134.5 (C, C-10a), 147.8 (C, C-3'), 148.6 (C, C-3), 161.2 (C, C-8), 161.3 (C, C-1'), 161.5 (CH, C-1), 162.4 (C, C-8'), 164.0 (C, C-6), 181.2 (C, C-10), 181.6 (C, C-10'), 190.5 (C, C-9). HR-ESI-MS : m/z 551.09876 [M-H] ${ }^{-}$(calc. 551.09837 for $\mathrm{C}_{31} \mathrm{H}_{19} \mathrm{O}_{10}{ }^{-}$).

Compound 1, 7,7'-emodinphyscion, was isolated as a yellow amorphous powder, for which the UV spectrum showed $\lambda_{\max }$ at 200,285, 440, $461 \mathrm{~nm}$ and in combination with the bathochromic shift after adding $\mathrm{NaOH}$ to $\lambda_{\max }$ at $287,522 \mathrm{~nm}$ indicating its anthraquinonic nature. Its molecular formula was determined as $\mathrm{C}_{31} \mathrm{H}_{20} \mathrm{O}_{10}$ by the HRESIMS [M-H] ${ }^{-}$ion at $\mathrm{m} / z 551.09876$ (calc. for $\mathrm{C}_{31} \mathrm{H}_{19} \mathrm{O}_{10}{ }^{-}$551.09837). ${ }^{1} \mathrm{H}$ NMR signals corresponding to aromatic rings of the dimeric anthraquinone skeleton were observed at $\delta_{\mathrm{H}} 7.64$ (br s-like), 7.58 (br s-like), 7.53 (br s), 7.34 (very br s), 7.28 (br s-like), and 7.24 (br s-like). Three of the five $\mathrm{OH}$ protons show relatively sharp singlets at $\delta_{\mathrm{H}} 12.50,12.18$, and 11.99 . The remaining two $\mathrm{OH}$ signals are too broad to be detected. Three singlets corresponding to three protons each belong to two methyl $\left(\delta_{\mathrm{H}} 2.51,2.49\right)$ and one $O$-methyl group $\left(\delta_{\mathrm{H}} 4.00\right)$. Based on the HMBC and NOE correlations as well as comparison with literature data of the structural related compounds 5 [22] and 6 [23], compound $\mathbf{1}$ was established as a new bisanthraquinone named 7,7'-emodinphyscion (Fig. 1). Some of the NMR signals could not be detected, presumably due to a hindered rotation around the biaryl axis resulting in severe signal broadening. Therefore, the proposed structure was verified by dehydration and alkaline oxidation of flavomannin C (5) according literature [23], which yielded 7,7'-emodinphyscion (1).

Repeated column chromatography of fraction 8 and 11 on Sephadex LH 20 (solvents methanol and acetone: methanol 4:1 v/v) resulted in detection of three known compounds 2-5. The structures of the isolated compounds 2-5 were determined based on their spectroscopic data $\left({ }^{1} \mathrm{H}-\mathrm{NMR},{ }^{13} \mathrm{C}-\mathrm{NMR}\right.$, ESIFTICR-MS, UV/Vis) and comparison with published data as dermolutein (2) (13.6 mg) [24, 25], endocrocin $(3)(8.1 \mathrm{mg})[24,25,26]$, skyrin $(4)(4.3 \mathrm{mg})$ [27] and the recently described dimeric pre-

\footnotetext{
${ }^{1}$ The taxonomic rank of Dermocybe is still object of discussion. Some mycologist regard Dermocybe as a separate genus [1,2], others insert Dermocybe as a subgenus in genus Cortinarius [3,4]. In accordance with chemical literature $[5,6]$ we treat here Dermocybe as a genus.
} 
anthraquinone derivative flavomannin $\mathrm{C}(\mathbf{5})(9.7 \mathrm{mg})$ [22]. The obtained spectral data of the isolated compounds 2-5 were in agreement with the relevant references.<smiles>Cc1cc(O)c2c(c1)C(=O)c1cc(O)c(-c3c(O)cc4c(c3O)C(=O)c3c(O)cc(C)cc3C4=O)c(O)c1C2=O</smiles>

7,7'-Emodinphyscion (1)<smiles>Cc1cc2c(c(O)c1C(=O)O)C(=O)c1c(O)cc(O)cc1C2=O</smiles>

Endocrocin (3)<smiles>COc1cc(O)cc2c1C(=O)c1c(cc(C)c(C(=O)O)c1O)C2=O</smiles>

Dermolutein (2)<smiles>Cc1cc(C)c(-c2c(O)cc(O)c3c2C(=O)c2cc(C)cc(O)c2C3=O)c(O)c1</smiles>

Skyrin (4)<smiles>COc1cc2cc3c(c(O)c2c(O)c1-c1c(O)cc2cc4c(c(O)c2c1O)C(=O)CC(C)(O)C4)C(=O)CC(C)(O)C3</smiles>

Flavomannin C (5)<smiles>Cc1cc(O)c2c(c1)C(=O)c1cc(O)c(-c3c(O)cc4c(c3O)-c3c(O)cc(C)cc3C4=O)c(O)c1C2=O</smiles>

7,7'-Biphyscion (6)<smiles>COc1cc2cc3c(c(O)c2c(O)c1-c1c(O)cc2cc4c(c(O)c2c1O)C(=O)CC(C)(O)C4)C(=O)CC(C)(O)C3</smiles>

Flavomannin-6,6'-di-O-methylether (7)

Figure 1. Isolated compounds from Dermocybe nahuelbutensis. 
Pigment pattern of the Dermocybe nahuelbutensis

This study reported for the first time the chemical investigation of fruiting bodies of $D$. nahuelbutensis, a mushroom so far only known from Chile. Around 18 Dermocybe species are named for South America (Argentinia, Chile), among them 10 species for Chile [21]. Two naturally occurring anthraquinones, dermolutein (2) and endocrocin (3), and the bisanthraquinone skyrin (4), well known from different Dermocybe species [5] as well as the dimeric pre-anthraquinone flavommanin C (5), so far only known from Talaromyces wortmannii, an endophyte of Aloe vera [22], were isolated from fruiting bodies of the Chilean mushroom D. nahuelbutensis (Fig. 1). Additionally, the structure of the new compound 7,7'emodinphysion (1), was determined according the spectroscopic data (Fig. 1). The occurrence of $\mathbf{1}$ may be an artefact formed during the isolation procedure of the dimeric pre-anthraquinone precursor flavomannin C (5). A similar origin was suggested for 7,7'-biphyscion (6), detectable in many European Dermocybespecies. In this case, flavomannin-6,6'-di- $O$-methylether (7), formed by oxidative coupling of two torosachrysone units, was suggested as potential precursor of 6 [5]. In European and North American taxa of Dermocybe, (pre-) anthraquinonoid pigments are important characters in species delimitation and in circumscription of sections within the genus [8, 15, 28]. Through the occurrence of dermolutein (2), endocrocin (3) and skyrin (4), D. nahuelbutensis shows a similar pigmentation pattern like Dermocybe species from the Northern hemisphere, but differs from Australasian and European species by the occurrence of 7,7'-emodinphyscion (1) and the mono- $O$-methyl dihydroanthracenone derivative flavomannin C (5). In opposite, oxidative 7,7' coupled di- $O$-methyl dihydroanthracenone derivatives like flavomannin-6,6'-di-O-methylether (7) are widespread in Dermocybe-species from the Northern hemisphere, but very rare in Australasian taxa and could so far only be detected in two species [6]. Therefore, we suggest from the chemotaxonomical point of view through the occurrence of the mono- $O$ methylated pigments such as 7,7'-emodinphyscion (1) and flavomannin C (5) in D. nahuelbutensis, that Chilean Dermocybe species present a separate linage in evolution of Dermocybe, which is more related to species of the Northern hemisphere than to Australasian species. This suggestion, based on pigmentchemical characters is meanwhile also supported on DNA level by the use of DNA sequences for recent phylogenetic studies in genus Cortinarius including Dermocybe [29].

\section{Acknowledgments}

This research work was financially supported by the BMBF (grant no. 01DN12107) and CONICYT (grant no. PCI 2011-609).

\section{Supporting information}

\section{References}

Supporting information can extracted on http://www.acgpubs.org/RNP

[1] M. Moser (1983). Kleine Kryptogamenflora, Band II b/2, Basidiomyceten: Die Röhrlinge und Blätterpilze, Kleine Kryptogamenflora. Gustav Fischer Verlag, Stuttgart, New York, pp. 1-533.

[2] Y. J. Liu, S. O. Rogers and J. F. Ammirati (1997). Phylogenetic relationships in Dermocybe and related Cortinarius taxa based on nuclear ribosomal DNA internal transcribed spacer, Can. J. Bot. 75, 519-532.

[3] U. Peintner, J. M. Moncalvo and R. Vilgalys (2004). Toward a better understanding of the infrageneric relationships in Cortinarius (Agaricales, Basidiomycota), Mycologia 96, 1042-1058.

[4] S. Garnica, M. Weiss and F. Oberwinkler (2003). Morphological and molecular phylogenetic studies in South American Cortinarius species, Mycol Res. 107, 1143-1156.

[5] M. Gill and W. Steglich (1987). Pigments of fungi, Progr. Chem. Org. Chem. Nat. Prod. 51, 1-297.

[6] M. Gill (1995). Pigments of Australasian Dermocybe toadstools, Aust. J. Chem. 48, 1-26.

[7] M. Gill (2001). The biosynthesis of pigments in Basidiomycetes, Aust. J. Chem. 54, 721-734.

[8] N. Arnold, H. Besl, A. Bresinsky and H. Kemmer (1987). Notizen zur Chemotaxonomie der Gattung Dermocybe (Agaricales) und zu ihrem Vorkommen in Bayern. Z. Mykol. 53, 187-194.

[9] M. Gabriel (1960). IV. Deuxième contribution à la connaissance de la pigmentation des Cortinaires des groupes Sanguinei et Cinnamomei, Ann. Univ. Sc. Nat. Lyon 11-12, 67-76.

[10] M. Gabriel (1960). Recherches sur les pigments des Agaricales. III. - Pigments des Cortinaires des groupes Cinnamomei et Sanguinei, Bull. Soc. Mycol. France 76, 208-215. 
[11] M. Gabriel (1961). V. Troisième contribution à lètude des pigments des Cortinaires des groupes Sanguinei et Cinnamomei (Elegantes Fries), Bull. Soc. Mycol. France 77, 262-272.

[12] M. Gabriel and D. Lamoure (1965). Cortinarius (Dermocybe) uliginosus Berk. var. luteus n. var., Bull. Soc. Mycol. France 81, 258-263.

[13] I. Gruber (1970). Anthrachinonfarbstoffe in der Gattung Dermocybe und Versuch ihrer Auswertung für die systematik, Z. Pilzk. 36, 95-112.

[14] K. Høiland (1981). Kanel-slørhattene (Cortinarius, underslægten Dermocybe) i Norden, Svampe 4, 63-73.

[15] K. Høiland (1983). Cortinarius subgenus Dermocybe, Opera Botanica 71, 1-113.

[16] G. Keller (1982). Pigmentationsuntersuchungen bei europäischen Arten aus der Gattung Dermocybe (Fr.) Wünsche, Sydowia 35, 110-126.

[17] G. Keller and J. F. Ammirati (1983). Chemotaxonomic significance of anthraquinone derivatives in North American species of Dermocybe, sect. Sanguineae, Mycotaxon 18, 357-377.

[18] R. H. Jones and T. W. May (2008). Pigment chemistry and morphology support recognition of Cortinarius austrocinnabarinus sp. nov. (Fungi: Cortinariaceae) from Australia, Muelleria 26, 77-87.

[19] G. Keller, M. Moser, E. Horak and W. Steglich (1987). Chemotaxonomic investigation of species of Dermocybe (Fr.) Wünsche (Agaricales) from New Zealand, Papua New Guinea and Argentina, Sydowia 40, 168-187.

[20] I. Gruber (1975). Papierchromatographische Pigmentanalyse von südamerikanischen Dermocyben und Cortinarien. In: M. Moser and E. Horak. Cortinarius Fr. und naheverwandte Gattungen in Südamerika, Beih. Nova Hewigia 52, 524-540.

[21] N. Garrido (1988). Agaricales s.l. und ihre Mykorrhizen in den Nothofagus-Wäldern Mittelchiles, Bibl. Mycol. 120, 1-528.

[22] R. Bara, I. Zerfass, A. H. Aly, H. Goldbach-Gecke, V. Raghavan, P. Sass, A. Mándi, V. Wray, P. L. Polavarapu, A. Pretsch, W. H. Lin, T. Kurtán, A. Debbab, H. Brötz-Oesterhelt and P. Proksch (2013). Atropisomeric dihydroanthracenones as inhibitors of multiresistant Staphylococcus aureus, J. Med. Chem. 56, 3257-3272.

[23] W. Steglich, E. Töpfer-Petersen, W. Reininger, K. Gluchoff and N. Arpin (1972). Isolation of flavomannin6,6'-dimethyl ether and one of its racemates from higher fungi, Phytochemistry 11, 3299-3304.

[24] W. Steglich, W. Lösel and V. Austel (1969). Pilzpigmente, IV. Anthrachinon-Pigmente aus Dermocybe sanguinea (Wulf. ex Fr.) Wünsche und D. semisanguinea (Fr.), Chem. Ber. 102, 4104-4118.

[25] M. Gill, P. M. Morgan, J. M. White and J. Yu (1998). Pigments of fungi. XLVII. Cardinalic acid, a new anthraquinone carboxylic acid from the New Zealand toadstool Dermocybe cardinalis and the synthesis and X-ray crystal structure of methyl 1,7,8-tri- $O$-methylcardinalate, Aust. J. Chem. 51, 213-218.

[26] Y. Asahina and F. Fuzikawa (1935). Untersuchungen über Flechtenstoffe, LV. Mitteil.: über Endocrocin, ein neues Oxy-anthrachinon-Derivat, Ber. dtsch. chem. Ges. 68, 1558-1565

[27] H. J. Banks, D. W. Cameron and W. D. Raverty (1976). Chemistry of the Coccoidea. II. Condensed polycyclic pigments from two Australian pseudococcids (Hemiptera), Aust. J. Chem. 29, 1509-1521.

[28] G. Keller and J. F. Ammirati (1995). Chemotaxonomic studies on the pigmentation of North American species of Dermocybe (Fr.) Wünsche, section Dermocybe and related species, Beih. Sydowia 10, 127-136.

[29] S. Garnica, M. E. Schön, K. Abarenkov, K. Riess, K. Liimatainen, T. Niskanen, B. Dima, K. Soop, T. G. Frøslev, T. S. Jeppesen, U. Peintner, R. Kuhnert-Finkernagel, T. E. Brandrud, G. Saar, B. Oertel and J. F. Ammirati (2016). Determining threshold values for barcoding fungi: lessons from Cortinarius (Basidiomycota), a highly diverse and widespread ectomycorrhizal genus, FEMS Microbiol. Ecol. 92, 1-16.

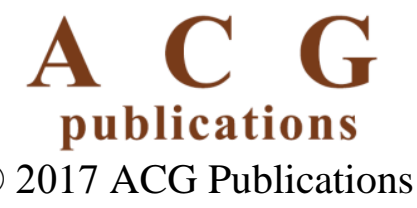

